\title{
INTERSTITIAL DENDRITIC CELLS OF THE HEART HARBOR TRYPANOSOMA CRUZI ANTIGENS IN EXPERIMENTALLY INFECTED DOGS: IMPORTANCE FOR THE PATHOGENESIS OF CHAGASIC MYOCARDITIS
}

\author{
SONIA G. ANDRADE, ARIANE R. PIMENTEL, MARCIA MARIA DE SOUZA, AND ZILTON A. ANDRADE \\ Laboratório de Doença de Chagas Experimental and Laboratório de Patologia Experimental, \\ Centro de Pesquisas Gonçalo Moniz-Fiocruz, Salvador, Bahia, Brazil
}

\begin{abstract}
Heart sections from 16 mongrel dogs, two normal controls and 14 infected with Trypanosoma cruzi, were submitted to immunohistochemical staining with either rabbit anti-cow S100 Protein monoclonal antibody or rabbit anti-T. cruzi purified specific antibody, using the peroxidase technique to investigate the participation of the interstitial dendritic cells of the heart (IDCs) in myocarditis of Chagas disease. Trypanosoma cruzi antigens were revealed as granular and dense deposits in IDC membrane in the heart of infected dogs both during acute and chronic myocarditis, but not in normal controls. Anti-S100 Protein labeled the IDCs, both in normal and infected dogs and a significant increase in the numbers of IDCs occurred in the myocardium, proportionally to the intensity of the inflammatory infiltration. These findings suggest that IDCs, probably by presenting $T$. cruzi antigens to immunecompetent cells, play an important role in the pathogenesis of Chagas disease.
\end{abstract}

\section{INTRODUCTION}

Interstitial dendritic cells (IDCs) of the myocardium were first described by Hart and Fabre. ${ }^{1}$ Immunohistochemistry with anti-MHC class II antibodies intensely stains these cells. Interstitial dendritic cells also exhibit the ability to bind to antigens and to stimulate $\mathrm{T}$ lymphocyte responses. ${ }^{2}$ They are recognized as specialized antigen-presenting cells that initiate immune response and can eventually migrate to the spleen, where they may have a significant role during heart transplant rejection. ${ }^{3}$ Migration of IDCs to the T-cell zone of the spleen may give rise to continuous sensitization of the heart to a delayed type hypersensitivity, the kind of immune reaction presently considered to be the main pathogenetic mechanism involved in Chagas disease myocarditis. ${ }^{4}$

Although a great deal of attention has been paid to the participation of several cell types in the pathogenesis of Chagas myocarditis, a role for IDCs has not yet been considered. Evidently, macrophages, lymphocytes, plasmocytes, as well as fibroblasts play important roles during host reactions against Trypanosoma cruzi antigens. The predominance of different subsets of lymphocytes, CD4 or CD8, which seems variable accordingly to the phase of the infection, has been thoroughly investigated..$^{5-7}$ However, whether myocardial IDCs play a role in this process has not been established. Therefore, the present study was designed to investigate the participation of IDCs in Chagas myocarditis, not only to complement data on cellular types involved in this inflammatory process, but also to further investigate the pathogenesis of myocarditis.

\section{MATERIALS AND METHODS}

Sixteen mongrel dogs were used in the present investigation: 14 experimentally infected with $T$. cruzi either in the acute or chronic phases of infection and two normal controls. Maintenance and care of experimental animals complied with the Centro de Pesquisas Gonçalo Moniz/Fiocruz guidelines for humane use of laboratory animals.

Acute phase. Six dogs weighing 1,100 to $3,200 \mathrm{~kg}$ were infected with the $12 \mathrm{SF}$ strain $\left(1 \times 10^{5}\right.$ trypomastigotes $/ \mathrm{kg}$ of body weight [b.w.]) or the $21 \mathrm{SF}$ strain of $T$. cruzi, $(4 \times$
$10^{5}$ trypomastigotes $/ \mathrm{kg}$ body weight), administered intraperitoneally (Table 1). Both parasite strains had previously been isolated from human cases of acute Chagas disease from São Felipe, BA, Brazil and characterized according to their biological behavior as biodeme Type II and their isoenzymic patterns as zymodeme Z2. ${ }^{8}$ Animals were examined daily. Parasitemic levels were evaluated weekly in peripheral blood drawn from the cephalic vein by venipuncture, and by counting the number of trypomastigotes in 50 microscopic fields $(\times 400)$. Pentobarbital sodium was used to kill the animals and complete autopsies were performed. Portions of the heart were fixed in paraformaldehyde and cryopreserved. Other portions of the heart were fixed in buffered $10 \%$ formalin, paraffin embedded, and sections used for histopathological or immunohistochemical techniques.

Chronic infected phase. Paraffin blocks of heart tissue from eight dogs were taken from the files. General data concerning inocula, duration of infection and histopathology, are presented in Table 2. Three dogs were infected with the Colombian strain, which was isolated from a human case in Colombia, and previously characterized by the biological characters as biodeme Type III and by the isoenzymic profils as zymodeme $\mathrm{Z}^{8}{ }^{8}$ (Inoculum: $5 \times 10^{4}$ blood forms $/ \mathrm{kg} \mathrm{b.w.)}$ Five dogs belonging to two groups, were infected with the 12 SF strain, being 3 with $6 \times 10^{4}$ and 2 with $1 \times 10^{5}$ blood forms $/ \mathrm{kg} \mathrm{b.w}$. These cases were representative of 1) $5 \mathrm{dogs}$ which presented diffuse chronic myocarditis following repeated treatment with low dose cyclophosphamide (Cy), as described elsewhere by Andrade and others; ${ }^{9}$ 2) one dog with spontaneous chronic T. cruzi myocarditis; and 3) two dogs sacrificed during the chronic indeterminate phase of infection.

Normal controls. Two healthy uninfected adult dogs were maintained in separate quarters, but under the same general conditions as the infected groups, and used as controls.

Immunohistochemical staining of interstitial dendritic cells of the heart. Immunohistochemical staining for IDCs was performed in 5 micron-thick cryostat sections obtained from cryopreserved tissues, as well as in 5 micron-thick sections from paraffin blocks. Either one of two primary antibodies were used: a commercially purchased monoclonal 

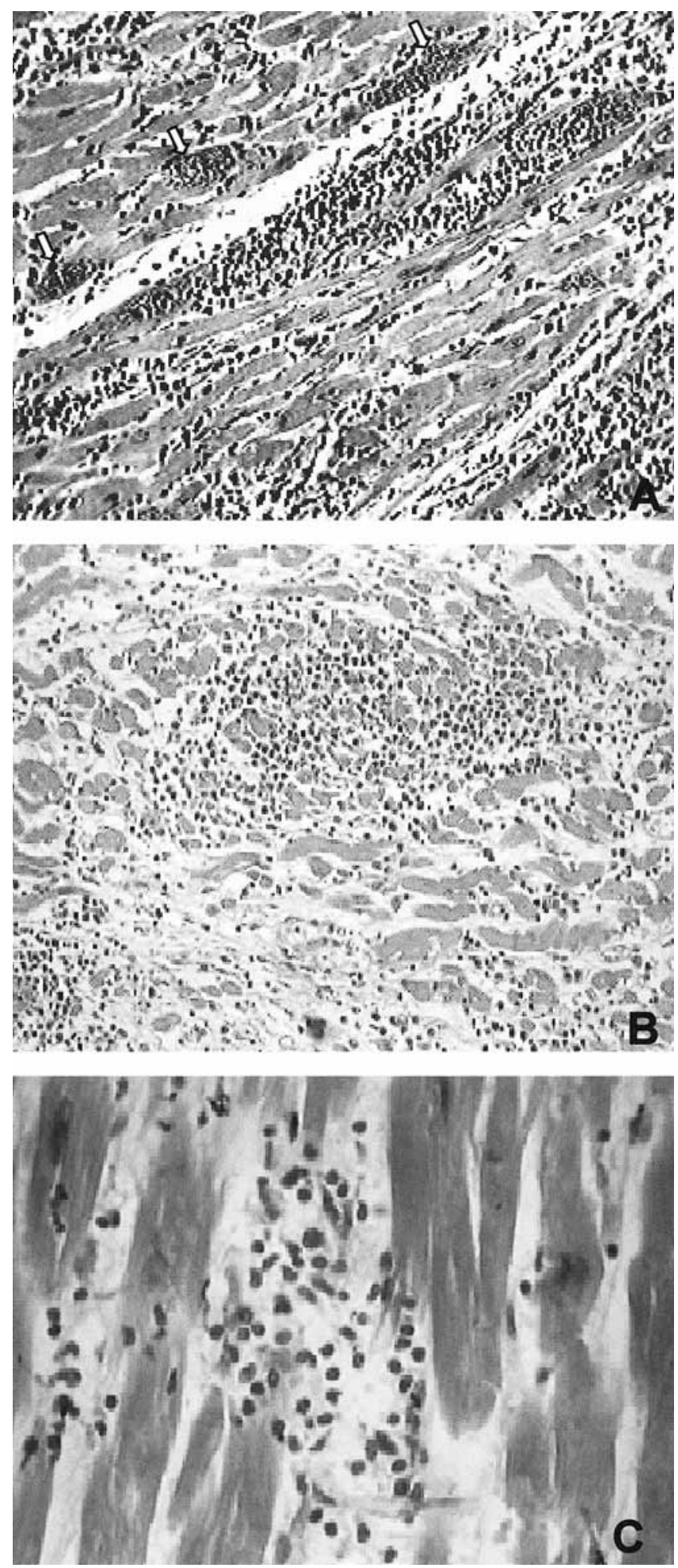

FIGURE 1. Histopathological aspects of the myocardium. A. Acute myocarditis with intense mononuclear inflammatory infiltration, focal destruction of myocytes and presence of intracellular amastigotes (arrows). (Hematoxylin and Eosin $\times 250$ ). B. Chronic diffuse myocarditis with focal destruction of cardiac myocytes; focal and diffuse mononuclear inflammatory infiltration and interstitial fibrosis. (Hematoxylin and Eosin $\times 250$ ). C. Chronic indeterminate form, showing mild focal myocarditis. (Hematoxylin and Eosin $\times$ 400).
TABLE 1

General data on dogs in the acute phase of infection with Trypanosoma cruzi

\begin{tabular}{ccccccc}
\hline $\begin{array}{c}\text { Case } \\
\text { no. }\end{array}$ & $\begin{array}{c}\text { Identifica- } \\
\text { tion } \\
\text { no. }\end{array}$ & T. cruzi strain & $\begin{array}{c}\text { Initial } \\
\text { weight }(\mathrm{g})\end{array}$ & $\begin{array}{c}\text { Inoculum* } \\
\text { (Tryp/kg/b.w.) }\end{array}$ & $\begin{array}{c}\text { Duration } \\
\text { (days) }\end{array}$ & $\begin{array}{c}\text { Degree of } \\
\text { infiltration }\end{array}$ \\
\hline 1 & 135 & $12 \mathrm{SF}$ & 2,200 & $1 \times 10^{5}$ & 25 & +++ \\
2 & 173 & $21 \mathrm{SF}$ & 1,100 & $4 \times 10^{5}$ & 26 & +++ \\
3 & 183 & $21 \mathrm{SF}$ & 2,500 & $4 \times 10^{5}$ & 34 & +++ \\
4 & 184 & $21 \mathrm{SF}$ & 2,900 & $4 \times 10^{5}$ & 34 & +++ \\
5 & 185 & $21 \mathrm{SF}$ & 2,500 & $4 \times 10^{5}$ & 32 & +++ \\
6 & 190 & $21 \mathrm{SF}$ & 3,200 & $4 \times 10^{5}$ & 34 & +++ \\
\hline
\end{tabular}

* Inoculum $=$ Number of trypomastigotes $/ \mathrm{kg} / \mathrm{body}$ weight.

$+++=$ intense and diffuse inflammatory infiltration.

anti-cow S100 Protein (for the identification of IDCs) and a purified specific anti-T. cruzi $\operatorname{IgG}$ obtained in rabbits. AntiS100 Protein is the purified IgG fraction of the antiserum produced in rabbits by injections with purified S-100 protein from bovine brain. It was used in the present investigation, because anti-dendritic antibodies specific for dogs are not yet available and since S100 protein is present in IDCs and can be labeled with the anti-S100 protein. ${ }^{10,11}$

Technical procedures. 1) Cryopreserved sections: fragments of the heart were fixed in a solution made of $4 \%$ paraformaldehyde, $0.1 \mathrm{M}$ cacodylate, and $7.5 \%$ sacharose, for 8 to $12 \mathrm{hr}$ at $4^{\circ} \mathrm{C}$. Following fixation, fragments were washed with $0.1 \mathrm{M}$ cacodylate $+0.2 \mathrm{M}(\mathrm{pH}$ 7.4) sacharose, for $12 \mathrm{hr}$ at $4^{\circ} \mathrm{C}$. Tissues were embedded in Tissue Teck and cryopreserved in liquid nitrogen. 2) Paraffin sections were treated with $100 \%$ xylene ( 2 baths of $15 \mathrm{~min}$ ) followed by acetone for $10 \mathrm{~min}$. Sections were hydrated in decreasing concentrations of ethanol in water and endogenous peroxidase was blocked with a solution of hydrogen peroxide $(0.3 \%)$ and methanol. Digestion was performed with a solution of trypsin (Sigma) at $0.1 \%$ with $\mathrm{CaCl}_{2}$ and $\mathrm{NaCl}, \mathrm{pH}$ 7.6 for $45 \mathrm{~min}$. Both deparaffinized and cryostat sections were submitted to the same procedures of immunostaining: sections were washed in phosphate buffer (PBS) $\mathrm{pH} 7.4$; non-specific reactions were blocked with $10 \%$ non-fat dry milk in PBS for $15 \mathrm{~min}$.

S100 Protein immunolabeling. Incubation took place for $1 \mathrm{hr}$ at $37^{\circ} \mathrm{C}$ in an humidified chamber with rabbit anti-cow S100 Protein monoclonal antibody (DAKO) diluted at 1:100 in PBS plus $2 \%$ Tween 20 and $1 \%$ bovine serum albumin. This was followed by treatment with normal serum during $20 \mathrm{~min}$ at room temperature; incubation with secondary biotinylated goat anti-rabbit antibody (Vectastain Elite ABC kit rabbit $\operatorname{IgG}$, Vector Lab PK6101), in the dilution of 1:20, during $30 \mathrm{~min}$ at $37^{\circ} \mathrm{C}$ and incubation with Vectastain $\mathrm{ABC}$ reagent in PBS in humidified chamber at $37^{\circ} \mathrm{C}$; the color was developed with $0.05 \% 3,3^{\prime}$-diaminobenzidine tetrahydrochloride (DAB) and $0.01 \% \mathrm{H}_{2} \mathrm{O}_{2}$ at room temperature. Sections were counterstained with $1 \%$ methyl-green for 2 min, dehydrated and mounted with Permount.

Trypanosoma cruzi antigen immunolabeling. Sections were treated with purified, specific anti-T.cruzi $\operatorname{IgG}$ produced in rabbits, in the dilution of 1:640 followed by biotinylated goat anti-rabbit IgG antibody (Vectastain Elite ABC kit, PK6101), following the same steps described above. Anti-T. cruzi antibodies were produced by two rabbits immunized with whole $T$. cruzi antigen extracted from culture forms of 

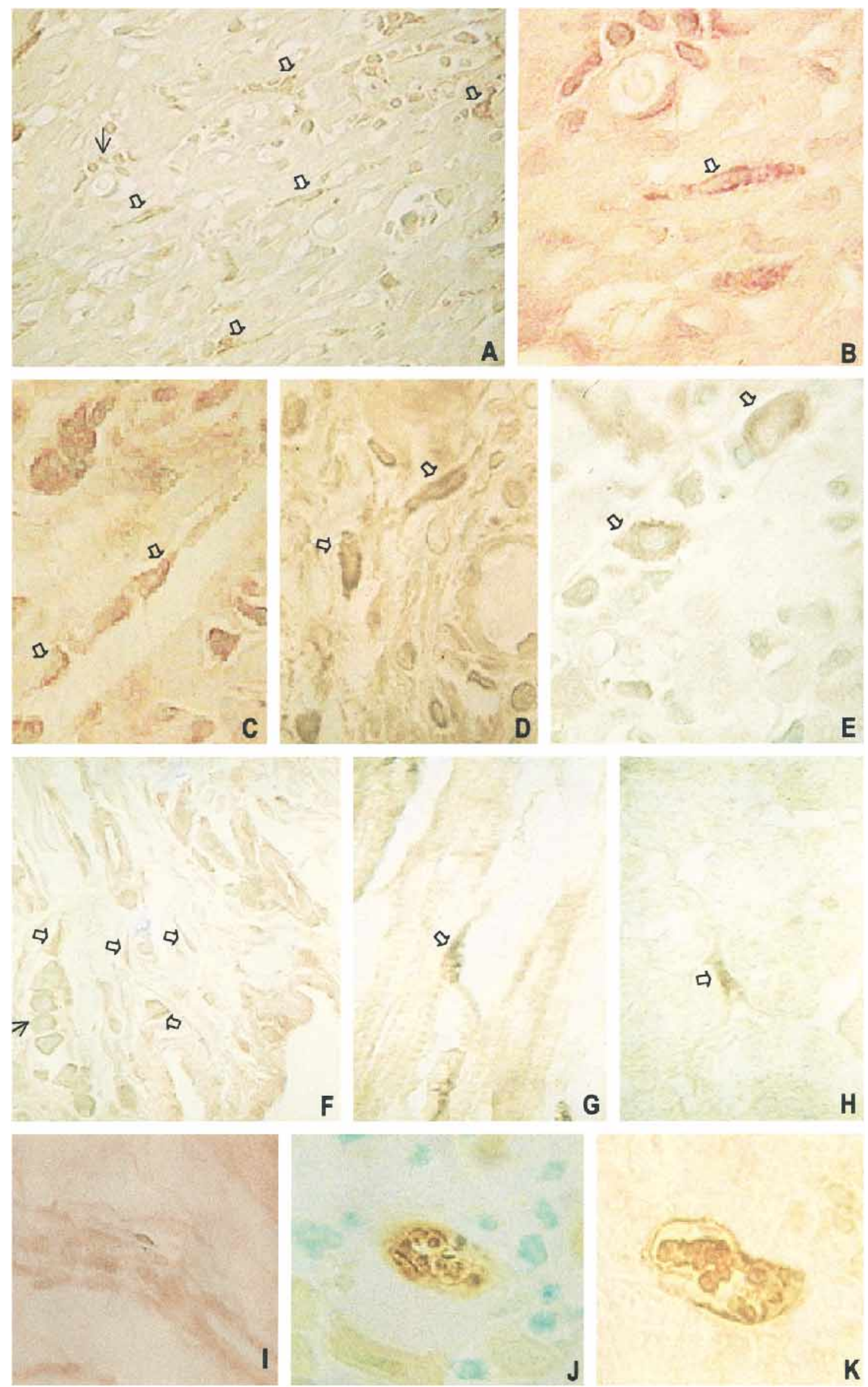

$\Rightarrow$
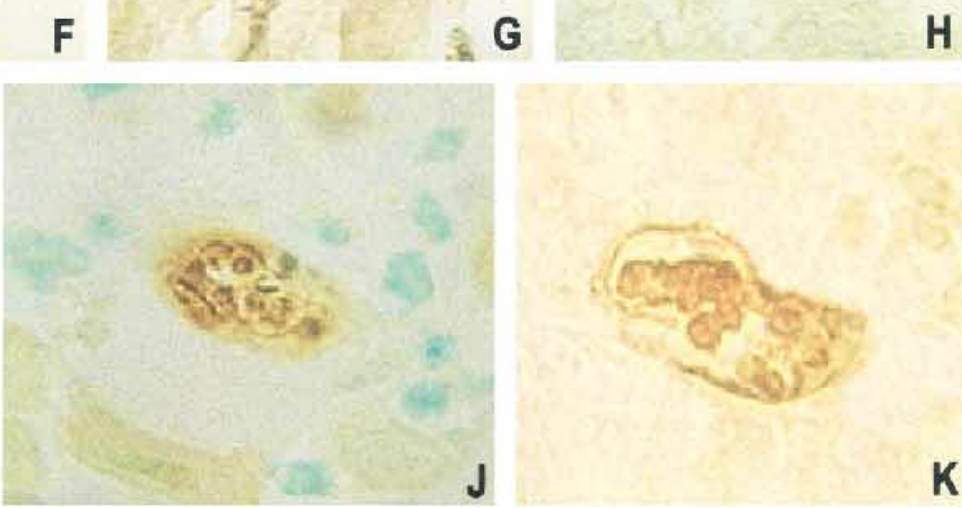

H

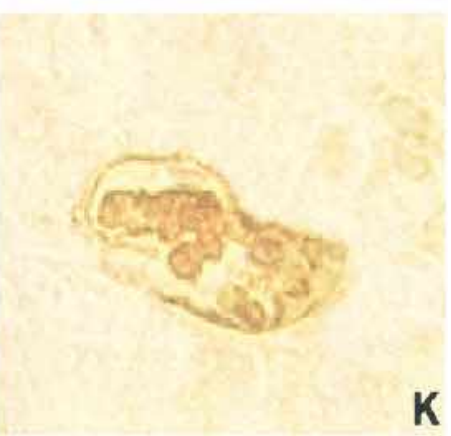


TABLE 2

General data on dogs chronically infected with Trypanosoma cruzi

\begin{tabular}{rrrllll}
\hline $\begin{array}{c}\text { Case } \\
\text { no. }\end{array}$ & $\begin{array}{c}\text { Identifi- } \\
\text { cation } \\
\text { no. }\end{array}$ & $\begin{array}{c}\text { Infection } \\
\text { (days) }\end{array}$ & T. cruzi strain & $\begin{array}{c}\text { Inoculum } \\
\text { (Tryp/kg/b.w.) }\end{array}$ & $\begin{array}{c}\text { Cyclophos- } \\
\text { phamide** }\end{array}$ & Myocarditis \\
\hline 7 & 74 & 338 & Colombian & $5 \times 10^{4}$ & Yes & CRDM \\
8 & 75 & 338 & Colombian & $5 \times 10^{4}$ & Yes & CRDM \\
9 & 82 & 338 & Colombian & $5 \times 10^{4}$ & Yes & CRDM \\
10 & 86 & 122 & $12 \mathrm{SF}$ & $6 \times 10^{4}$ & Yes & CRDM \\
11 & 87 & 122 & $12 \mathrm{SF}$ & $6 \times 10^{4}$ & Yes & CRDM \\
12 & 112 & 213 & $12 \mathrm{SF}$ & $1 \times 10^{5}$ & No & MFM \\
13 & 115 & 213 & $12 \mathrm{SF}$ & $1 \times 10^{5}$ & No & MFM \\
14 & 129 & 94 & $12 \mathrm{SF}$ & $6 \times 10^{4}$ & No & CRDM
\end{tabular}

Inoculum $=$ Number of trypomastigotes (blood forms) $/ \mathrm{kg}$ body weight.

* Treatment with low doses of Cyclophosphamide.

CRDM = chronic diffuse myocarditis; MFM = mild focal myocarditis (indeterminate form).

the parasite, obtained from Warren culture medium (Bacto Brain Heart Infusion, DIFCO Laboratories, Detroit, MI). Parasites were washed three times in PBS, $\mathrm{pH}$ 7.2, submitted successively to freezing in liquid nitrogen and thawing, and mixed in complete Freund's adjuvant. Serum tested by indirect immunofluorescence showed titers of 1:640 specific for $T$. cruzi. Gamma globulin was precipitated with ammonium sulphate, dialysed in PBS, $\mathrm{pH}$ 7.0, and purified a second time using Sephadex for separation of IgG antibodies. A third purification was performed in $\mathrm{CnBr}$ sepharose with $T$. cruzi antigen. The eluate containing the specific antibodies was concentrated with polyethylene-glycol.

Quantitative evaluation of IDCs in the immunostained heart sections. The number of IDCs was counted in $5 \mathrm{mi}-$ croscopic fields, not successively, using an ocular $10 \times$ and an objective $40 \times$. Counting was performed on paraffin sections of heart tissue from control and infected dogs during acute and chronic infections. Statistical analysis of results was performed by unpaired $t$-test. The mean and standard deviation (SD) was established for each case and the number of cells $/ \mathrm{mm}^{2}$ calculated. The mean $( \pm \mathrm{SD})$ of the measurements obtained for each group in sections of the heart (either acute and chronic infection), immunolabeled with either anti-S100 Protein or anti-T. cruzi antibodies, were compared with normal controls labeled with anti-S100 Protein. Comparison was also made between the groups of chronic diffuse myocarditis (CRDM) and the indeterminate form with mild focal myocarditis (MFM).
TABLE 3

Interstitial dendritic cells (IDCs) in normal control dog hearts

\begin{tabular}{cc}
\hline Normal controls & $\begin{array}{c}\text { Number of IDCs pmm } \\
\text { anti-S100 protein }\end{array}$ \\
\hline C1 & $29.8 \pm 14.5$ \\
C2 & $44.8 \pm 10.8$ \\
Mean & $37.30 \pm 7.5$ \\
\hline
\end{tabular}

$\mathrm{C} 1=$ control no. $1 ; \mathrm{C} 2=$ control no. 2

RESULTS

Non-infected control dogs showed hearts histologically within normal limits. Interstital dendritic cells were demonstrated by immunohistochemistry with anti-S100 Protein antibodies in the interstitial tissue of the normal myocardium. Cells were elongated, isolated, and uniformly distributed with scanty, compact cytoplasm, a central, round, pale nucleus, and two or three fine cytoplasmic processes with bior tripolar extensions, which sometimes gave the cell a fusiform or triangular appearance.

For the dogs with acute $T$. cruzi infection, intense myocarditis was present in all cases, as shown in Table 1, characterized by intense and diffuse inflammatory infiltration (grade +++ ), more prominent in the atrial wall (Figure 1A). Variable degrees of damage in parasitized and non-parasitized myocells associated with diffuse and focal mononuclear and also focal polymorphonuclear infiltration were present, as previously described. ${ }^{12}$ During the chronic indeterminate stage of infection, a mild focal myocarditis was present in two dogs that had not been treated with Cy (Table 2). Cardiac lesions were rare, with small mononuclear inflammatory infiltrates involving the interstitial myocardium and subendocardium as shown in Figure 1C. Previous description of these infiltrates by electron microscopy has shown evidences of apoptosis of lymphocytes, macrophages, and plasmocytes, determining a self-control of inflammation in this phase. ${ }^{13}$

A chronic diffuse myocarditis (Table 2) was present in dogs chronically infected with $T$. cruzi and treated with low dose $\mathrm{Cy},{ }^{9}$ characterized by intense inflammatory infiltration (Figure 1B), and focal damage of myocardiocytes. In one non-Cy-treated dog a CRDM was also seen; this case represents an early evolutive chronic myocarditis, 94 days postinfection. Two types of heart lesions were present: focal destruction of cardiac myocells with scattered foci of mono-

$\leftarrow$

Figure 2. Sections of the heart of dogs infected with Trypanosoma cruzi, submitted to immunohistochemistry staining with peroxidase and revealed with diaminobenzidine (DAB), for immunolabeling of interstitial dendritic cells (IDCs), using as primary antibodies either antiS100 Protein or anti-T. cruzi purified antibodies: A, B, C, and D. Acute myocarditis: IDCs appear labeled with anti-T. cruzi antibodies, with its peculiar morphology and localization, in the interstitium and associated with inflammatory infiltration. A. General view showing several IDCs revealing the presence of $T$. cruzi antigens on the membrane (arrows) in the presence of lymphocytes infiltration (thin arrow) ( $\times$ 400). B. Higher magnification of one cell (white arrow) in A. showing dense granular, deposits in the membrane ( $\times 1,000)$. C. and D. IDCs labeled with anti-T. cruzi antibody, related to the inflammatory infiltrates $(\times 1,000)$. E. Acute myocarditis with macrophages exhibiting $T$. cruzi antigens in the cytoplasm. F. Chronic myocarditis in a dog treated with cyclophosphamide (Cy): several IDCs are labeled with anti-S100 protein (arrows), showing their typical morphology and localization; lymphocytic infiltration (thin arrow) is present ( $\times 1,000)$. G. Chronic indeterminate form, presence of IDC-positive for $T$. cruzi antigen, in a dog not treated with Cy $(\times 1,000)$. H. Preserved area of the myocardium in a dog treated with $\mathrm{Cy}$, that presented a chronic myocarditis, showing isolated IDCs, with positive immunolabeling for anti- $T$. cruzi antibodies $(\times 1,000)$. I. Section of the heart of a normal control dog, showing IDC-positive staining with anti-S100 Protein ( $\times$ 400). J. Acute infection. Intracellular amastigotes with positive nuclear and kinetoplast reaction for anti-S100 Protein but the parasite membrane is negative $(\times 400)$. K. Acute infection. Anti-T. cruzi antibodies gave a coarse granular cytoplasmic staining of amastigotes and clearly depicted their external membrane and kinetoplast $(\times 1,000)$. 
TABLE 4

Quantitative evaluation of interstitial dendritic cells (IDCs) in the heart of dogs infected with Trypanosoma cruzi

\begin{tabular}{|c|c|c|c|}
\hline \multicolumn{4}{|c|}{ Acute infection } \\
\hline \multirow[b]{2}{*}{ Case no. } & \multirow[b]{2}{*}{ Identification no. } & \multicolumn{2}{|c|}{ No. of dendritic cells $/ \mathrm{mm}^{2 *}$} \\
\hline & & Anti-S100 protein & Anti-T. cruzi \\
\hline 1 & 135 & $83.1 \pm 18.4$ & $63.9 \pm 34.3$ \\
\hline 2 & 173 & $79.2 \pm 13.9$ & $73.8 \pm 27.2$ \\
\hline 3 & 183 & $106.9 \pm 21.0$ & $83.7 \pm 14.4$ \\
\hline 4 & 184 & $97.6 \pm 21.5$ & $80.9 \pm 21.5$ \\
\hline 5 & 185 & $98.0 \pm 15.6$ & $92.3 \pm 31.7$ \\
\hline \multirow[t]{3}{*}{6} & 190 & $79.5 \pm 9.2$ & $92.3 \pm 23.5$ \\
\hline & Mean $\pm \mathrm{SD}$ & $90.7 \pm 4.7$ & $81.1 \pm 4.5$ \\
\hline & Normal & & \\
\hline & Control & $37.3 \pm 7.5$ & \\
\hline $\begin{array}{l}\text { Statistical } \\
\text { Analysis } \dagger\end{array}$ & & $P=0.0013 \ddagger$ & $P=0.0027 \S$ \\
\hline
\end{tabular}

nuclear inflammatory infiltration and diffuse mononuclear cells infiltration with focal concentrations in the peri-vascular space and fibrous thickening of the interstitial matrix.

Identification of IDCs was possible by immunostaining with the anti-S100 Protein monoclonal antibody. In sections treated with anti-T. cruzi antibodies, IDCs appeared strongly stained (Figures $2 \mathrm{~A}-\mathrm{D}, \mathrm{G}$, and $\mathrm{H}$ ) and with their characteristic morphological features, as seen when anti-S100 Protein antibody was used (Figure 2F). Not only the morphological appearance but also the distribution of the IDCs was similar in sections treated either with anti-S100 Protein or anti-T. cruzi antibodies. However, IDCs in the hearts of normal controls failed to stain with anti-T. cruzi antibodies. In the presence of myocarditis, IDCs were seen to be more concentrated around areas of focal myocardial infiltrations and near parasitized cardiac myocells, forming clusters of three or more elongated and characteristic dendritic cells associated with lymphocytes (Figures 2A, C, and D). In the preserved areas of the myocardium, IDCs were rare and appeared isolated in the interstitium on the myocyte membrane (Figures $2 \mathrm{G}$ and $\mathrm{H}$ ). Besides the IDCs, macrophages in the infiltrates occasionally presented positive reaction for $T$. cruzi particulated antigens into the cytoplasm, revealed by the staining of anti-T. cruzi antibodies (Figure 2E).

Intracellular amastigotes showed positive nuclear and kinetoplast reaction for anti-S100 Protein, but the parasite membrane remained negative (Figure 2J). Anti-T. cruzi antibodies gave a coarse granular cytoplasmic staining of amastigotes and clearly depicted their external membrane (Figure 2K).

Quantitative evaluation of IDCs. Table 3 shows the quantitative evaluation of the IDCs in normal dogs. The IDCs were increased in number in Chagas myocarditis, acute or chronic diffuse, as demonstrated by quantitative analysis (Tables 4-6). Statistical analysis (considering a level of significance of $P<0.05$ revealed significant increase in the number of IDCs in cases of acute infection, as seen in sections labeled with anti-S100 $(P=0.0013)$ or anti-T.cruzi $(P$ $=0.027)$ antibodies, as compared with the normal controls (Table 4). The same was true when cases of chronic diffuse myocarditis were compared to normal controls $(P=0.006$,
TABLE 5

Evaluation of number of interstitial dendritic cells (IDCs) in the hearts of dogs in the chronic phase of infection with Trypanosoma cruzi that show chronic diffuse myocarditis

\begin{tabular}{|c|c|c|c|}
\hline \multirow[b]{2}{*}{ Case no. } & \multirow[b]{2}{*}{ Identification no. } & \multicolumn{2}{|c|}{ Number of IDCs $/ \mathrm{mm}^{2}($ mean $\pm \mathrm{SD})$} \\
\hline & & Anti-S100 protein & Anti-T. cruzi \\
\hline 7 & 74 & $98.0 \pm 21.5$ & $90.8 \pm 9.2$ \\
\hline 8 & 75 & $108.2 \pm 26.6$ & $76.5 \pm 10.5$ \\
\hline 9 & 82 & $159.0 \pm 34.8$ & $66.0 \pm 19.1$ \\
\hline 10 & 86 & $86.6 \pm 10.5$ & $61.0 \pm 26.3$ \\
\hline 11 & 87 & $123.5 \pm 29.8$ & $78.1 \pm 7.1$ \\
\hline \multirow[t]{3}{*}{14} & 129 & $126.3 \pm 63.5$ & $84.2 \pm 11.2$ \\
\hline & Mean $\pm \mathrm{SD}$ & $116.9 \pm 10.4$ & $76.1 \pm 4.5$ \\
\hline & Controls & $37.3 \pm 7.5$ & \\
\hline Statistical analysis* & & $P=0.0062 \dagger$ & $P=0.0051 \ddagger$ \\
\hline
\end{tabular}

for anti-S100 Protein and $P=0.005$, for anti-T.cruzi) (Table 5). Comparing the number of IDCs in the indeterminate form and controls, no significant statistical difference was detected (Table 6).

\section{DISCUSSION}

The present study demonstrates for the first time that cells morphologically identified as IDCs, can be immunohistochemically stained with specific anti-T. cruzi antibodies, in the interstitium of the myocardium of dogs with acute and chronic Chagas myocarditis. The significance of this finding for the pathogenesis of Chagas myocarditis seems evident, since IDCs are antigen-presenting cells to immune-competent $\mathrm{T}$ lymphocytes. Interstitial dendritic cells from normal animals, identified by S100 Protein-positive staining, did not react with anti- $T$. cruzi antibodies, which indicates that the staining observed in IDCs of infected animals is due to the presence of $T$. cruzi antigen(s).

In a previous study, Andrade and others ${ }^{14}$ demonstrated the presence of $T$. cruzi antigens in the cell membrane of follicular dendritic cells of the spleen, using immunoelectron microscopy in mice with chronic $T$. cruzi infection. This finding correlates with the persistence of a positive serology in mice free of parasites by chemotherapy. Follicular dendritic cells are present in the germinal centers of lymph follicles of the spleen and are important antigen-presenting cells to lymphocyte-B memory cells. Thus, the present demonstration of $T$. cruzi antigens in IDCs of the heart, repre-

TABLE 6

Evaluation of number of interstitial dendritic cells (IDCs) in the hearts of dogs in the chronic phase of infection with Trypanosoma cruzi showing the indeterminate form (mild focal myocarditis)

\begin{tabular}{|c|c|c|c|}
\hline \multirow{2}{*}{$\begin{array}{l}\text { Case } \\
\text { no. }\end{array}$} & \multirow{2}{*}{$\begin{array}{c}\text { Identification } \\
\text { no. }\end{array}$} & \multicolumn{2}{|c|}{ Number of IDCs/mm² (mean $\pm \mathrm{SD})$} \\
\hline & & Anti-S100 protein & Anti-T. cruzi \\
\hline 12 & 112 & $56.8 \pm 8.6$ & $41.1 \pm 19.6$ \\
\hline 13 & 115 & $58.2 \pm 19.6$ & $26.9 \pm 9.2$ \\
\hline \multicolumn{2}{|c|}{ Mean $\pm \mathrm{SD}$} & $57.5 \pm 0.7$ & $34.0 \pm 7.1$ \\
\hline \multicolumn{2}{|c|}{ Normal control } & $37.3 \pm 7.5$ & \\
\hline \multicolumn{2}{|c|}{ Statistical analysis* } & $P=0.1155 \dagger$ & $P=0.7847 \ddagger$ \\
\hline
\end{tabular}


sentative of lymphoid dendritic cells, ${ }^{2}$ indicates the involvement of both types of dendritic cells in humoral (spleen) and cellular (heart) responses during the course of Chagas disease.

Considering the migratory capacity of the IDCs, ${ }^{2,3}$ it is possible that such cells present in the myocardium can migrate to the T-cell compartment of the spleen. From there and from the myocardium proper, IDCs are able to participate in the immunological process in Chagas myocarditis, considering the role of these cells in presentation of antigens in association with MHCII products and the sensitization of $\mathrm{T}$ cells for the production of cytokines involved in pathogenetic mechanisms. ${ }^{15-17}$ Recently it has been shown that IDCs express IL-12 in response to specific antigen (Staphylococcus aureus $)^{18}$ by interaction with T cells. It is possible that $T$. cruzi antigen stimulation of IDCs could also determine similar IL-12 response, considering that surface glycoprotein molecules from both trypomastigotes and amastigotes have been shown to induce cytokine synthesis by inflammatory macrophages: IL1, IL-6, IL-12, and TNF $\alpha .{ }^{19}$ The complexity of the subject does not preclude the interpretation that both IDCs and T. cruzi components are involved in the immunological responses in Chagas myocarditis. Characterization of the inflammatory cells involved in the different phases of infection has suggested that all the classes of lymphocytes are polyclonally activated during the acute phase with a profile of antibodies typical of CD4-T celldependent response, but also with the participation of CD8 lymphocytes..$^{20}$ Probably the mechanisms of delayed hypersensitivity are present from the acute phase ${ }^{5}$ with predominance of CD4 lymphocytes. However, the importance of CD8 lymphocytes has been emphasized by Tarleton ${ }^{6}$ in the acute phase of infection and by Zhang and Tarleton ${ }^{21}$ in chronic infection.

Spontaneously-developed $T$. cruzi chronic myocarditis is rare in dogs. Low dose Cy transforms latent infection into a chronic progressive myocarditis as has been demonstrated by Andrade and others. ${ }^{9}$ The influence of Cy on IDCs has been shown by Limpens and others ${ }^{22}$ with an enhancement of accessory cell function for interdigitating cells of lymph nodes. Quantitative evaluation of myocardial IDCs revealed an increased number in acute and chronic myocarditis, when compared with the normal controls or the indeterminate form of disease suggesting a direct relationship between the number of IDCs and the intensity of the inflammatory infiltration.

In rats with experimental myocardial infarction, Zhang and others ${ }^{23}$ registered an increase in the number of IDC per $\mathrm{mm}^{2}$ in the border of the infarcted zone and suggested that this increase is due to the recruitment of dendritic cells from bone marrow. In the acute phase, chemotatic stimuli that originated from the parasitism of cardiac cells and their rupture, with liberation of antigenic products, can be considered to be an important factor for the increased number of dendritic cells in the myocardium of dogs infected with $T$. cruzi. However, the presence of apoptosis of these cells in this phase, occurring together with the apoptosis of the inflammatory cells, myocytes, and parasites, has also been detected. ${ }^{24}$ Apoptosis of the IDCs could be a cause of failure of antigen presentation in this phase of infection.

Parasite antigens have been identified in focal inflammatory infiltrates of chronic Chagas myocarditis, both in mice ${ }^{25}$ and in humans. ${ }^{26,27}$ However, the diffuse, evolutive, fibrotic, and inflammatory lesions seen in Chagasic myocarditis, compatible with a cell-mediated immune response, probably involves a continuous stimulation of cellular immunity, through the presentation of parasite antigens by IDCs to T lymphocytes.

Acknowledgments: We thank Dr. Moysés Sadigursky for preparing the anti-T. cruzi antibodies used in this investigation.

Financial support: This research was supported by the Programa de Apoio à Pesquisa Estratégica em Saúde (PAPES-Fiocruz).

Authors' addresses: Sonia G. Andrade and Ariane R. Pimentel, Laboratório de Doença de Chagas Experimental, Centro de Pesquisas Gonçalo Moniz/Fiocruz, Rua Valdemar Falcão, 121, CEP, 41815340, Salvador, Bahia, Brasil; Telephone: 071-356-4320, E-212, FAX: 071-3564292. Marcia Maria de Souza and Zilton A. Andrade, Laboratório de Patologia Experimental, Centro de Pesquisas Gonçalo Moniz/ Fiocruz, Rua Valdemar Falcão 121, CEP, 41815-340, Salvador, Bahia, Brasil; Telephone: 071-356-4320, E-206, FAX: 071-3562155.

Reprint requests: Sonia G. Andrade, Laboratório de Doença de Chagas Experimental, Centro de Pesquisas Gonçalo Moniz/Fiocruz, Rua Valdemar Falcão, 121, CEP, 41815-340, Salvador, Bahia, Brasil; Telephone: 071-356-4320, E-212, FAX: 071-3564292

\section{REFERENCES}

1. Hart DNJ, Fabre JW, 1981. Demonstration and characterization of a Ia-positive dendritic cells in the interstitial connective tissues of rat heart and other tissues, but not brain. J Exp Med 153: 347-361.

2. Hart DNJ, McKenzie JL,1990. Interstitial dendritic cells. Int Rev Immunol 6: 127-138.

3. Larsen CP, Morris PJ, Austyn JM, 1990. Migration of dendritic leucocytes from cardiac allografts into host spleens. $J$ Exp Med 171: 307-314.

4. Andrade ZA, 1991. Pathogenesis of Chagas' disease. Res Immunol 142: 126-129.

5. Ribeiro dos Santos R, Pirmez C, Savino W, 1991. Role of autoreactive immunological mechanisms in chagasic carditis. Res Immunol 142: 134-137.

6. Tarleton RL, 1991.The role of T-cell sub-populations in experimental Chagas'disease. Res Immunol 142: 130-133.

7. Dos Reis G, 1997. Cell-mediated immunity in experimental Trypanosoma cruzi infection. Parasitology Today 13: 335-340.

8. Andrade SG, Magalhães JB, 1997. Biodemes and zymodemes of Trypanosoma cruzi strains: Correlations with clinical data and experimental pathology. Rev Soc Bras Med Trop 30: 2735.

9. Andrade ZA, Andrade SG, Sadigursky M, 1987. Enhancement of chronic Trypanosoma cruzi myocarditis in dogs treated with low doses of Cyclophosphamide. Amer J Pathol 127: 467-473.

10. Turner RR, Wood GS, Beckstead JH, Colby TV, Horning SJ, Warnke RA, 1984. Histiocytic malignancies. Morphologic, immunologic and enzymatic heterogeneity. Am Surg Pathol 8: 485-500.

11. Daum GS, Liepman M, Woda BA, 1985. Dendritic cell phenotype in localized malignant histiocytosis of the small intestine. Arch Pathol Lab Med 109: 647-650.

12. Andrade ZA, Andrade SG, Corrêa R, Sadigursky M, Ferrans VJ, 1994. Myocardial changes in acute Trypanosoma cruzi infection. Ultrastructural evidence of immune damage and the role of microangiopathy. Amer J Pathol 144:1403-1411.

13. Andrade ZA, Andrade SG, Sadigursky M, Wenthold RJ Jr, Hilbert SL, Ferrans VJ, 1997. The indeterminate phase of Chagas' disease: ultrastructural characterization of cardiac changes in the canine model. Amer J Trop Med Hyg 57: 328-336.

14. Andrade SG, Freitas LAR, Peyrol S, Pimentel AR, Sadigursky M, 1991. Experimental chemotherapy of Trypanosoma cruzi 
infection: persistence of parasite antigens and positive serology in parasitologically cured mice. Bull WHO 69: 191-197.

15. Steinman RM, 1988. Cytokines amplify the function of accessory cells. Immunol Lett 17:197-202.

16. Steiman RM, 1991. The dendritic cell system and its role in immunogenicity. Anпu Rev Immunol 9: 271-296.

17. Inaba K, Young JW, Steiman RM, 1987. Direct activation of CD8 cytotoxic T lymphocytes by dendritic cells. J Exp Med 166: $182-194$.

18. Heufler C, Koch F, Stanzl U, Topar G, Wysocka M, Trinchieri G, Enk A, Steiman RM, Romani N, Schuler G, 1996. Interleukin-12 is produced by dendritic cells and mediates $\mathrm{T}$ helper 1 development as well as interferon-gamma production by $\mathrm{T}$ helper 1 cells. Eur J Immunol 26: 659-668.

19. Brener Z, Gazzinelli RT, 1997. Immunological control of Trypanosoma cruzi infection and pathogenesis of Chagas'disease. Int Arch Allergy Immunol 114: 103-110.

20. Minoprio P, 1991. Chagas'disease: CD5 B-cell-dependent Th2 pathology? Res Immunol 142: 137-140.

21. Zhang L, Tarleton RL, 1996. Persistent production of inflammatory and anti-inflammatory cytokines and associated MHC and adhesion molecule expression at the site of infection and disease in experimental Trypanosoma cruzi infections. Exp Parasitol 84: 203-213.

22. Limpens J, van Meijer M, van Santen HM, Germeraad WTV, Hoeben-Schornagel K, Breel M, Scheper RJ, Kraal G, 1991.
Alterations in dendritic cell phenotype and function associated with immunoenhancing effects of a subcutaneously administered cyclophosphamide derivative. Immunology 73: 255263.

23. Zhang J, Yu ZX, Fujita S, Yamaguchi ML, Ferrans VJ, 1993. Interstitial dendritic cells of the rat heart. Quantitative and ultrastructural changes in experimental myocardial infarction. Circulation 87: 909-920.

24. Zhang J, Andrade ZA, Yu ZX, Andrade SG, Takeda K, Sadigursky M, Ferrans VJ, 1999. Apoptosis in a canine model of acute chagasic myocarditis. J Mol Cell Cardiol 31: 581-596.

25. Younes-Chenouffi AB, Hontebeyrie-Joscowicz M, Tricottet V, Eissen H, Reynes M, Said G, 1988. Persistence of Trypanosoma cruzi antigens in the inflammatory lesions of chronically infected mice. Trans $R$ Soc Trop Med Hyg 82: 77-83.

26. Higuchi ML, De Brito T, Reis MM, Barbosa A, Bellotti G, Pereira Barreto AC, Pileggi F, 1993. Correlation between Trypanosoma cruzi parasitism and myocardial inflammatory infiltrate in human chronic chagasic myocarditis: light microscopy and immunohistochemical findings. Cardiovasc Pathol 2: $101-106$.

27. Jones EM, Colley DG, Toste SJ, Lopes ER, Vnencak-Jones CL, McCurley TL, 1993. Amplification of a Trypanosoma cruzi DNA sequence from human inflammatory lesions in human chagasic cardiomyopathy. Amer J Trop Med Hyg 48: 348357. 